\title{
Tenure-neutral and Equitable Housing Taxation
}

\author{
Philippe Thalmann
}

[Paper first received, August 2005; in final form, April 2006]

Summary. Equity and neutrality are distinct concepts in housing taxation and weak and strong tenure neutrality should be distinguished. When a tax system is tested for those criteria, the taxes paid by landlords must be included, as they affect the rents renters pay. This paper defines appropriate tests, applies them to a stylised tax system and proposes tax changes designed to restore tenure equity and/or neutrality. It shows how the homeowner's implicit income should be computed for taxes to be fundamentally tenure-neutral or equitable or both. It also shows the key role played by the cost differential in producing housing services under owner-occupation and renting.

\section{Introduction}

The tax advantage to homeowners is traditionally measured by reference with full imputation of the implicit rent as income for tax purposes (see for example, Aaron, 1970). The implicit rent is taken to be the market rent for an equivalent dwelling, from which the homeowner should be allowed to deduct mortgage interest and operating costs. There are two problems with that approach, one practical and one conceptual. The practical problem is estimating the market rent for an equivalent dwelling, or the rent at which the homeowner could let his dwelling to a renter, or the rent a landlord would charge him for that dwelling. Sometimes national averages are used to eliminate quality differences, but the 'average' rental apartment is certainly of lower quality than the 'average' owner-occupied housing unit.

The conceptual problem is simply that it is not clear why the market rent for the dwelling should be used to measure the homeowner's

implicit income and even less clear why he should be taxed on that basis. Feldstein (1976) challenged that view, so it is necessary to return first to basic principles of equity and neutrality of housing taxation. We do so in this paper, with a view to providing the tools for setting up a tenure-neutral and equitable housing tax system.

A related branch of the literature examines the relative costs of owner-occupied and rental housing and their impact on tenure choice (for example, Rosen and Rosen, 1980, Hendershott and Shilling, 1982). Taxes play an important role in that comparison as they constitute a much easier way to measure difference than management and maintenance costs. That literature generally concludes that personal income tax advantages can substantially favour homeownership (Rosen, 1984), implying that the tax system is not neutral with respect to tenure choice. In fact, what that literature shows is that the 
user cost for owner-occupied housing is a smaller proportion of the dwelling's price than the user cost of rental housing. That might be offset to some extent by a premium for dwellings sold to owner-occupiers, particularly when tax advantages are partly capitalised.

It is not that obvious to draw conclusions about the non-neutrality of housing taxation from that literature. Indeed, differences in user costs mingle differences in tax treatment and differences in production costs. In addition, there exists some confusion about the meaning of neutrality. Tenure neutrality is generally interpreted as equal costs for rental and owner-occupied housing, presumably of the same quality (for example, Englund, 2003). Haffner (2003) provides an overview of the possible meanings of tenure neutrality, ranging from equal cash outlays by renters and homeowners to equal public spending for either mode. She concludes that equality of user costs is the appropriate concept: "if user costs differed between tenures, they could be equalised, in order to remove any distortion of consumers' choice" (p. 84). In that interpretation, a public policy seeking tenure neutrality would iron out all differences in user costs created by housing and tax policy but also by market forces. Lundqvist goes even farther

A neutral policy would include legal measures to make tenures alike in terms of freedom of disposal and security of tenure. Systems of housing finance, and terms of repayment, would be structured in such a way as to neutralise the impact of ability to pay on household choice of tenure (Lundqvist, 1986, p. 16).

Note, however, that Lundqvist does not show how those concepts could be tested.

Such requirements go too far. They attempt to make all players equally strong where levelling the playing-field and letting the best win is more conducive to efficiency. Instead, we shall define a tenure-neutral tax and subsidies system as one that preserves the ordering of user costs-whichever tenure is cheaper before tax is still cheaper after tax. Under certain conditions, a stronger neutrality condition might be warranted: a tax system is strongly neutral if it preserves the absolute difference in user costs.

Obviously, tenure choice cannot be reduced to a comparison of user costs (Shelton, 1968), but it is a component of that choice that public authorities can influence, mainly through taxation. Numerous countries encourage homeownership through tax advantages. Some European authorities may appear less generous, as they tax an imputed income for the homeowner. This contribution will define the benchmark with which the tax systems ought to be compared in order to determine the generosity of tax advantages granted to homeowners.

User costs depend on particular circumstances: the type of landlord, the terms at which he can borrow funds compared with the homeowner, the types of dwelling occupied, the length of residence and the holding period, the timing of purchase and sale over the real estate cycle, the performance of the local housing market and so forth. No tax system can be tenure-neutral under all circumstances. Our goal here is to define an income tax system that is fundamentally tenureneutral-i.e. it is tenure-neutral when the economic differences between the two tenures are reduced to plain structural differences.

When tenure neutrality is carefully defined, it appears that it is not equivalent to tenure equity. Roughly speaking, and that definition will be refined, the tax system is equitable with respect to tenures if it collects more from households in the cheaper tenure, because their capacity to contribute is higher. An equitable tax system might affect tenure choice and thus not be neutral, by reducing the advantage of the cheaper tenure. On the other hand, an inequitable tax system might well be tenure-neutral, by favouring that tenure which is already more advantageous.

Public finance analysts are familiar with testing the equity of an income tax system for household categories by considering taxable incomes and deductibles. They 
seldom consider the taxation of commodities, even when its incidence is higher prices. Indeed, it is held that these taxes are like consumption taxes, that all households bear them similarly in proportion of their consumption. That is not true for housing, the largest item in most households' budget. Taxes levied on the production of rental housing servicestaxes paid by landlords - are not borne by homeowners. This paper shows that landlord taxation must be included in the examination of the tenure equity and neutrality of housing income taxation, and how to do so.

Section 2 defines those terms and concepts in greater detail. It will propose to replace the concept of 'user cost' by that of 'available income', which allows addressing both neutrality and equity. It also introduces the modelling approach with which housing taxation will be assessed. Actual modelling starts in section 3, with the minimum mathematics required to formalise the concepts. It defines available incomes and arbitrage conditions in the absence, first, of all taxes. Thus, section 3 provides the tax-free benchmarks against which the influence of taxation on tenure choice and its equity will be measured. Section 4 introduces taxes in their most general form into user costs and available income and section 5 defines tenure equity and neutrality as conditions on those taxes. Section 6 illustrates the approach on the basis of a stylised tax system that is similar to those found in European countries. Section 7 assesses a number of common or possible housing taxation systems on their tenure equity and neutrality. Section 8 summarises the results of that assessment and concludes.

\section{Concepts, Terminology and Modelling Approach}

When we consider housing taxation from the point of view of equity, we define it simply as the condition that taxes paid reflect capacity to contribute and we focus on the differential treatment of renters and homeowners. Capacity to contribute is generally measured by income. Suppose, however, that there exists a commodity that all households must buy, but it comes at two prices: a low price reserved to some households and a high price for all the others. Households that may buy the commodity at the low price have higher income available for other goods. Should capacity to contribute not take that advantage into account? We believe that it should. ${ }^{1}$

The commodity we have in mind is of course housing, which comes at one price as owner-occupied housing and at another as rental housing. Owner-occupied housing is out of reach for many households. If it is a cheaper arrangement, because housing production costs are less for the homeowner than the landlord, households that can benefit from it have higher capacity to contribute. We shall call 'available income' the income after housing costs. Tax equity requires the household to pay the same amount of taxes in both tenures if available incomes are equal (horizontal equity) and to pay more taxes in the tenure that leaves more available income (vertical equity). One should add an additional condition: the available income that is higher before taxes should not be lower after taxes for that would amount to a marginal tax rate of more than 100 per cent on the production cost advantage of the cheaper tenure. ${ }^{2}$ A tax system that is equitable under those conditions leads to after-tax available incomes that are closer than before taxes.

It may be difficult to accept that taxes should depend on income reduced by optional consumption spending (for housing). Indeed, that approach should not be used to compare the taxes paid by two households in the same tenure that decide to spend different amounts for housing. It is only valid for examining how taxes discriminate between a renter and a homeowner when it is the same household occupying the same dwelling in two different tenures. This is the narrow sense in which tax equity is defined here, with focus on tenure. We shall see that the full set of taxes pertaining to housing must be included when testing tax equity between renting and owning, including the taxes paid by the landlord. Again, it is unusual to include taxes comprised in consumption goods when assessing the equity of household income taxation. 
Indeed, one may generally admit that those taxes are borne by all households equally. That assumption is wrong in the case of housing. Only the renter bears the taxes paid by the landlord, while the homeowner escapes them.

Of course, we also consider housing taxation from the point of view of neutrality, simply defined as the condition that taxes do not change the ordering of available incomes between renters and homeowners. In other words, the tax system is tenure-neutral if the tenure that leaves a household the highest available income before taxes still does so after taxes. This condition shall be called 'weak tenure neutrality', as opposed to 'strong tenure neutrality', which requires that the difference in available incomes be exactly maintained after taxes. Under strong neutrality, the more advantageous tenure not only remains so after taxes but it remains so by exactly the same difference.

Tenure choice is commonly defined as a comparison of user costs. The homeowner's user cost includes actual outlays-interest, operating costs and taxes-as well as components that imply no expenditure-tax savings, the opportunity cost of equity, capital gains or losses. The renter's user cost essentially corresponds to rent paid, possibly lowered by personal housing aid. The tax system affects the renter's user cost mainly indirectly, through the rent that reflects the taxes paid by the landlord. In addition, the renter pays income tax on the returns on his financial wealth, which the homeowner invested in his home. User cost is directly linked to available income since available income plus user cost is equal to ordinary income before housing consumption. Thus, the difference in user costs between renting and owning is equal to the difference in available incomes between owning and renting. Since available income is the more natural concept to define tax equity, we shall also use it for defining tax neutrality.

Income taxes might also affect property prices, particularly if landowners and developers can capitalise a part of the tax savings enjoyed by homeowners. At this first stage, however, we wish to concentrate on the tax system in partial equilibrium (as opposed to a general equilibrium with endogenous prices and categories of owners and renters). This is a common and quite acceptable approach when comparing two assetsowner-occupied and rental housing - that are not taxed that differently after all. ${ }^{3}$

In principle, the effects of taxation on property prices could be captured by using prices and rents observed on the markets for the calculation of user costs or available incomes. Elsinga (1996), for instance, carefully compared particular rental and owner-occupied units of the Dutch Randstad, selected to be of equivalent quality. She interviewed households about the purchase price of their housing, which allowed her to set up a sort of price index, as the owners had bought their houses at different dates. The change in that index is a central component in her annual user cost of owner-occupied housing; so much so that it dominates the comparison in user costs. During the first half of the 1980s, when house prices were stable, the user cost of owner-occupied housing was higher than that of rental housing. The strong rise in house prices during the second half of the 1980s exactly reverses the comparison. The mortgage interest rate also plays an important role in the comparison, as it seems to affect only the user cost of owner-occupied housing. ${ }^{4}$ Indeed, a surprising result of Elsinga's research is that rents do not reflect changes in interest rates and property prices: they grow perfectly monotonously in the Netherlands. She thus showed that homeowners are exposed to considerable risks, risks that landlords seem to absorb completely when they set rents. As a result, homeownership, just like common stocks, is an asset that can only be recommended to investors who calculate their returns over a very long horizon-or who do not care about true costs.

Elsinga's research illustrates the volatility of empirical user costs. It may be more advantageous to own one's home in a certain year, when real estate prices grow and interest rates are low, and less advantageous the next year, when prices decline and interest rates rise. In order to obtain a general result on 
the relative costs of owner-occupied housing, one could compute the user costs over several years. Still, the date of purchase-peak or trough-would remain crucial, as well as the date at which a fixed-rate mortgage (the vast majority of mortgage credits in the Netherlands) was taken up. As a general matter, annual changes in real estate prices and interest rates may dwarf all other differences between renting and owning, notably tax differences.

We wish to develop here a model that makes it possible to compare tenures in long-run equilibrium, like for example, Capone (1995), in order to find evidence of stable underlying determinants, such as taxation. Our model describes the average available incomes, without computing the mean of annual available incomes. On the side of the homeowner, it resembles closely the usual models of user costs, including capital and operating costs. On the renter's side, available income is ordinary income minus the rent, but that rent is computed to reflect the landlord's costs (as in Shelton, 1968; and Poterba, 1990). We therefore postulate that the landlord passes those costs on to his tenant in such a way that he earns his required return over the whole investment period (and not necessarily in every individual year).

In order to insulate tax differences from differences in housing consumption, we assume that the homeowner and the renter occupy the same dwelling, which the homeowner and the landlord buy at the same price and which appreciates at the same rate irrespective of who owns it. In other words, the two dwellings are in the same property market. Capital gains are taxed at rates that may differ between owner-occupied and rental dwellings. The accrual equivalent capital gains taxes will be included in the model but we will ignore the fact that property owners can lower those equivalent tax rates and sometimes even the statutory capital gains tax rate by holding their property longer. Similarly, we ignore taxes that must be paid once at the time of purchase or sale and which therefore represent a higher burden for shorter holding periods. We claim that such taxes should not be included in the test of the tenure neutrality of the tax system because they are designed to discriminate between shorter and longer holding periods, not between renting and owning. One could say that our model is designed to test only income taxation related to housing.

One fundamental economic difference between renting and owning we shall allow for, and it will play an important role: the difference in costs of producing housing services, depending on whether a renter or a homeowner-occupies the apartment. That difference may be due to management costs and faster depreciation for rental housing. We shall thus focus on differences between the available incomes of the renter and the homeowner that are introduced by the tax system and by 'production costs'.

\section{Available Incomes in the Absence of Taxes}

Our representative household can choose to rent or to own its dwelling. We assume this to be the same dwelling to eliminate differences in quality. When owning its dwelling, the household invests $W$, a part of its wealth that would otherwise earn interest at rate $i^{*}$. Asterisks mark incomes before taxes. The household's other incomes are grouped under $Y^{*}$. As a tenant, it pays rent $R^{*}$. As a homeowner, it bears direct production costs $K^{O}$ encompassing all operating costs (maintenance, ${ }^{5}$ repair, gardening, insurance, electricity, water, heating) as well as depreciation and interest paid on the mortgage. The property appreciates by an amount $G$, which is added to the homeowner's available income under the assumption that he could use this amount as collateral for borrowing.

As indicated in section 2, tenure tax equity and neutrality ought to be defined with reference to 'available income', which is equal to income minus housing costs. If the household rents its dwelling, its available income is, in the absence of all taxes

$$
Y^{R^{*}}=Y^{*}+i^{*} W-R^{*}
$$


If the same household owns its dwelling, its available income is

$$
Y^{O^{*}}=Y^{*}-K^{O}+G
$$

When the household chooses to rent its home, it does so from a landlord. In order to avoid tainting the comparison of the tax treatment of owner-occupied with rental housing by the particular nature of the landlord, we assume that he is the alter ago of the homeowner, locating in the same tax brackets and using the same wealth to purchase the same dwelling at the same price (presumably the seller of the dwelling would not know whether the purchaser buys it for his own use or for letting) which appreciates by the same amount. ${ }^{6}$

Obviously, landlords need not be the same people as homeowners, tax differences having the potential to encourage a certain specialisation. However, in the OECD country with the largest share of rental housing, Switzerland, 57.4 per cent of all rental dwellings belong to individuals (2000 census). Even in that country, rental units are not the same as owned apartments: among owner-occupied dwellings, the share of single-family houses is 57 per cent while that share is only 5 per cent among rental dwellings (2000 census). Shelton (1968) saw the rental and owner-occupied markets as related though separated. Ten years later, White and White (1977) emphasised that rental and owner-occupied housing are substitutes in supply, not only for developers but also for landlords who have the option to sell their dwellings to individual households, possibly the renters themselves.

The landlord's available income is $Y^{*}+$ $i^{*} W$ if he just keeps his wealth invested in the reference asset. If he buys rental property, his available income in the absence of taxes is

$$
Y^{L^{*}}=Y^{*}+R^{*}-K^{L}+G
$$

where $K^{L}$ corresponds to similar direct production costs as the homeowner's $K^{O}$. The rental property appreciates by the same amount $G$ as the owner-occupied property as it is assumed to be in the same market. The landlord's available income is the same whether he owns rental property or not when the rent is equal to full production costs $C^{L^{*}}$

$$
C^{L^{*}}=i^{*} W+K^{L}-G
$$

The landlord earns a normal return if the rent covers operating and financial costs, including the required return on equity, minus property appreciation. Full production costs can be defined similarly for owner-occupied housing, as the difference between the homeowner's income if he does not own a home and his available income when he does

$$
\begin{aligned}
C^{O^{*}} & =\left(Y^{*}+i^{*} W\right)-Y^{O^{*}} \\
& =i^{*} W+K^{O}-G
\end{aligned}
$$

When the market rent is equal to full production costs, the difference in the homeowner's and renter's available incomes reduces to

$$
Y^{O^{*}}-Y^{R^{*}}=K^{L}-K^{O}
$$

This difference measures the increase in available income when a household buys its rental dwelling. It is equal to the difference in direct production costs $K$ and not full production costs $C$ because the opportunity cost of funds and property appreciation are assumed to be the same for the landlord and the owner-occupant.

The market rent is equal to costs when competition among landlords is sufficient, which is an empirical question. Blackley and Follain (1996) found, with the help of a dynamic econometric model for the US rental housing market, that a 10 per cent increase in landlord costs has rents increase by 6 per cent, but only after 200 years. After 5 years, real rents are only 1 per cent higher and 1.7 per cent after 10 years. DiPasquale and Wheaton (1992) had even estimated a smaller impact on rents, of the order of 0.8 per cent for a 10 per cent shock.

We could salvage our assumption of rents equal to costs by arguing that, even if it takes a long time for production cost changes to translate into changes in rents and the translation is only partial, rents may 
still best be explained by production costs, provided they do not change too often. We could also refer to second-generation rent control, where rents are not allowed to exceed costs. Such a defence is not necessary. Suppose that the landlord's return $R^{*}-K^{L}+$ $G$ exceeds $i^{*} W$. In that case, the renter also invests $W$ in rental housing and his available income is

$$
\begin{aligned}
Y^{R^{*}} & =Y^{*}+\left(R^{*}-K^{L}+G\right)-R^{*} \\
& =Y^{*}-K^{L}+G
\end{aligned}
$$

Subtracting equation (7) from equation (2) yields the same difference between the homeowner's and the renter's available incomes as in equation (6), even when the market rent is greater than full production costs. To see the intuition behind this result, consider a situation where housing shortage allows landlords to charge rents that exceed their costs and earn an extraordinary return. The homeowner escapes the rise in rent that the renter must bear, but on the other hand he forgoes the option to earn that extraordinary return, his wealth being locked in his dwelling. Overall, he is indifferent from the rise in rents. Equation (7) is a more general definition of the renter's available income than equation (1) as it also holds when market rents exceed full production costs.

The difference in available incomes is quite robust to the investment options assumed for the household that chooses to rent and to the relationship between rent and costs. We shall see that this is still true when taxes are included and when we compute the difference in before- and after-tax available incomes of the renter and homeowner separately.

The difference in available incomes when owning or renting is equal to the difference between the financial and other costs incurred by the landlord in providing housing services and those directly borne by the homeowner. It is likely that the landlord's housing production costs are different from the homeowner's because they include management fees (manager, janitor) and because a rented apartment might wear faster and require more maintenance. Englund (2003) noted that the landlord pays management and maintenance fees at labour costs that include payroll taxes whereas the opportunity cost of the homeowner's own management and maintenance time is the wage rate after income tax. In some European countries, there is a factor of two to three between the two labour costs. Henderson and Ioannides (1983, p. 100) identified a 'fundamental rental externality', corresponding to that part of "marginal costs of increased breakdowns and wear and tear caused by increased rates of utilisation" that cannot be charged to the tenant due to incomplete rental contracts. Shilling et al. (1991) adopted the same principal-agent view. Linneman (1985) called the direct costs differential 'relative landlord production efficiency', which can be positive or negative. ${ }^{7} \mathrm{He}$ referred to

superior credit ratings, greater political influence which yields lower tax assessments, maintenance cost efficiencies, or economies associated with processing a landlord's credit application versus that for a homeowner (Linneman, 1985, p. 233).

The landlord's production efficiency is particularly great in multifamily units, where he is better able to handle neighbourhood disputes and solve free-rider problems with respect to the maintenance of common facilities. On the other hand, the landlord's production efficiency is offset by opportunistic behaviour under the incomplete contract between landlord and tenant, which requires expensive monitoring and entails externalised costs. Linneman did not estimate landlord production efficiency but he computed critical values for which renting is financially equally attractive as owning. For most plausible parameters, those values are less than one, which corresponds to smaller production efficiency for landlords than for homeowners.

We are not aware of many empirical estimates of the direct costs differential. One can see why when considering the additional wear and tear. The 'normal' costs in the reference situation, those of owner-occupied housing, are indistinguishable from spending for home improvements. Thus, when Shilling 
et al. (1991) showed that single-family houses occupied by renters depreciate faster than those that are occupied by their owner, that might simply mean that homeowners choose to spend more on maintenance, not that they have to. Harding et al. (2000) used similar data to show that highly indebted homeowners spend less on maintenance, which might indicate that maintenance spending depends more on the funds available than on the actual wear and tear. ${ }^{8}$ Thus, the data on maintenance spending and housing depreciation are not easily informative about underlying wear and tear. What are needed are data on spending required to maintain a dwelling at constant quality. Lacking such data, some authors simply assume costs for landlords that homeowners need not bear, such as management costs. ${ }^{9}$ For our purpose, it is sufficient that landlords face different direct costs than homeowners.

\section{Available Incomes with Taxes}

The same letters without asterisks now stand for after-tax incomes, in particular the interest rate $i$ on equity and other incomes $Y$. All income taxes paid by the homeowner in direct connection with his dwelling, annualised, are grouped in $T^{O}$. That includes the accrual-based equivalent of the capital gains tax that is due upon selling the property. The renter's specific housing taxes are grouped in $T^{R}$. They are most likely to be negative in countries where renters are granted an allowance for rents in the definition of taxable income $^{10}$ or any form of direct housing subsidy reserved to rental housing, which does not imply that renters pay no taxes at all, only that renting a home lowers their taxes. The available incomes of the renter and homeowner with taxes are

$$
\begin{aligned}
& Y^{R}=Y+i W-R-T^{R} \\
& Y^{O}=Y-K^{O}+G-T^{O}
\end{aligned}
$$

The landlord faces his own set of taxes on rental housing income, denoted $T^{L}$. His alternative investment is the same financial asset earning after-tax interest $i$. Hence, he compares his available income as a landlord

$$
Y^{L}=Y+R-K^{L}+G-T^{L}
$$

with the income he earns by holding the reservation asset, $Y+i W$. The two are equal when the rent is equal to full production costs $C^{L}$

$$
C^{L}=i W+K^{L}-G+T^{L}
$$

Full production costs of rental housing services include the after-tax opportunity cost of funds and the taxes the landlord pays, but they are lowered by property appreciation. Similarly, full production costs for owneroccupied housing $C^{O}$ are the difference between the homeowner's after-tax income if he does not own a home and his available income when he does

$$
\begin{aligned}
C^{O} & =(Y+i W)-Y^{O} \\
& =i^{*} W+K^{O}-G+T^{O}
\end{aligned}
$$

When the market rent is equal to the full production costs of rental housing services $\left(R=C^{L}\right)$, the difference in available incomes with taxes is, using equations (8), (9), and (11)

$$
\begin{aligned}
Y^{O}-Y^{R}= & K^{L}-K^{O}+T^{L}+T^{R} \\
& -T^{O}
\end{aligned}
$$

Thus, the difference between the available incomes of the homeowner and the renter depends on the difference in financial and other costs and taxes incurred in providing housing services, augmented by the specific housing taxes of the renter. The taxes paid by the landlord cannot be ignored when testing the incidence of the tax system on tenure choice (i.e. tenure neutrality), as they affect the renter's available income. If the costs of producing housing services are the same for rental and owner-occupied housing, the difference in available incomes reduces to a difference in taxes. Without taxes, the available incomes differ by the production costs (equation (6)).

Testing the equity and neutrality of the tax system will require comparing the taxes paid by the homeowner with those he would pay 
as a landlord owning the same dwelling. It is perfectly possible that the production costs are higher for rental than for owner-occupied housing services $\left(K^{L}>K^{O}\right)$, but that rental housing is a tax shelter (for example, thanks to accelerated depreciation allowances), so that $T^{L}<T^{O}$. If that tax advantage is passed on to the renter, he could end up with higher available income than the homeowner (Titman, 1982).

We can show rapidly that the difference in available income is unchanged when the market rent exceeds full production costs. In that case, the renter invests his equity $W$ into rental property where he earns more than $i W$. His available income is

$$
\begin{aligned}
Y^{R} & =Y+\left(R-K^{L}+G-T^{L}\right)-R-T^{R} \\
& =Y-K^{L}+G-T^{L}-T^{R}
\end{aligned}
$$

Subtract this from the homeowner's available income in equation (9) to obtain the same difference as in equation (13).

\section{Equity and Neutrality}

Taxation is equitable if it reduces the difference between available incomes between the tenures, but not so that the household (or team) that has higher net income before taxes ends with lower net income after taxes. The difference in available incomes before taxes $\Delta Y^{*}=Y^{O^{*}}-Y^{L^{*}}$ is equal to the difference in direct production costs $\Delta K=$ $K^{L}-K^{O}$ (equation (6)). From equation (13), the difference in available incomes after taxes $\Delta Y^{*}=Y^{O}-Y^{L}$ is equal to $\Delta K-\Delta T$ with

$$
\Delta T=T^{O}-T^{L}-T^{R}
$$

Tenure equity as just defined requires that the tax system reduce the absolute value of the difference in available incomes

$$
|\Delta K-\Delta T|<|\Delta K|
$$

which is equivalent to

$$
0<\frac{\Delta T}{\Delta K}<1 \text { when } \Delta K \neq 0, \text { and } \Delta T=0
$$

when $\Delta K=0$
Tax neutrality with respect to tenure choice obtains when taxes do not reverse the sign of the difference in available incomes between the homeowner and the renter or, put differently, when the tenure that yields greater available income before taxes also yields greater available income after taxes. This corresponds, for other motives, to one of the equity conditions

$$
\begin{aligned}
& \frac{\Delta T}{\Delta K}<1 \text { when } \Delta K \neq 0, \text { and } \Delta T=0 \\
& \quad \text { when } \Delta K=0
\end{aligned}
$$

Neutrality allows imposing greater taxes on the tenure that has lower production costs. However, the difference in taxes should not be greater than the difference in those costs. Contrary to equity, it is perfectly compatible with neutrality to levy a heavier tax on the mode of tenure that already has a higher production cost.

Condition (18) is sufficient for the neutrality of housing taxation only to the extent that the choice of tenure depends on the sign of the difference in available incomes. We shall say that taxation is weakly tenureneutral when it does not reverse the sign of the difference in available incomes. It is quite possible, however, that tenure choice depends on the very difference in available incomes-say because there must be a sufficient economic advantage to becoming a homeowner to justify the sacrifices needed to accumulate the required equity. To be strongly tenure-neutral, taxation would have to leave that difference unchanged. Strong tenure neutrality requires $\Delta T=0$ even when $\Delta K \neq 0$. A tax system that is strongly tenure-neutral is equitable only in a very weak sense, as the renter and the homeowner pay the same amount of taxes even when their pre-tax available incomes differ.

We have made no distinction between households. If the available income is greater in one tenure than in the other, all households should choose the former. If they do not, it must be that they are influenced by factors that are not directly related to available incomes. Those factors could be gathered in a 
personal minimum difference in available incomes, $D_{i}$, that would be required for household $i$ to choose to own its home rather than rent it. Thus, household $i$ chooses to own its home if $Y^{O}-Y^{R}>D_{i}$. It rents its home if the contrary is true. With this approach, neutrality should be redefined as requiring that taxes do not change the sign of $Y^{O}-Y^{R}-D_{i}$-i.e. this expression should have the same sign as $K^{L}-K^{O}-D_{i}$. One would therefore need personalised conditions for each household. If one wishes to dispense from that, neutrality must be strong.

Our definition of neutral housing taxation is not the only possible one. Haffner (2000) defines tax neutrality as a condition that owner-occupied housing be taxed like all other investment goods. That definition places the household's choice of how to invest its savings at the centre of the analysis. It requires quite naturally full taxation of implicit rents and taxation of capital gains in the same way as those on other assets. Our definition of tax neutrality emphasises the household's choice of tenure. We shall see that full taxation of implicit rents is not required. We share with Haffner the focus on taxes and subsidies, leaving out land use and building code regulation, which also have an impact of housing costs but do not discriminate between tenures.

\section{A Stylised Tax System}

The model elaborated in the previous sections allows testing the equity and neutrality of almost any housing income taxation system. This is illustrated in this section with a stylised system that is sufficiently flexible to reproduce the main principles applied in many European countries. It has elements, such as an imputed rent, that existed in 9 out of 20 OECD countries in 1993 (OECD, 1994). ${ }^{11} \mathrm{We}$ also test a deductible for renters.

The income tax is levied at the locally flat rate $t,{ }^{12}$ so that after tax the other income is $Y=(1-t) Y^{*}$ and the income from the reservation financial asset is $i W=(1-t) i^{*} W$. As a renter, the household may be allowed to deduct $D^{R}$ from his other income in connection with his rental contract. It is worth

$$
T^{R}=-t D^{R}
$$

The landlord is taxed on imputed rental income $I^{L}$ (generally but not necessarily the rent he actually earns), from which he may deduct direct costs $K^{L}$ and supplementary deductibles $D^{L}$ such as an allowance for energy-saving investments, accelerated depreciation or the permission to claim as maintenance some expenditure that in fact increases the value of the property. In addition, he owes capital gains taxes when he sells his property, which we include in the annual income tax liability by imputing a proportion $\left(1-e^{L}\right)$ of accrued capital gain $G$. The coefficient $e^{L}$ is the tax-exempt proportion of accrued capital gain, corresponding at least to the advantage of tax deferral. It depends on the length of the holding period and the terms of real estate capital gains taxation. A different coefficient $e^{o}$ may apply to the homeowner's capital gain, in particular when rolling it over through the purchase of another home allows further deferral. Altogether, the landlord's tax liability is

$$
T^{L}=t\left[I^{L}-K^{L}-D^{L}+\left(1-e^{L}\right) G\right]
$$

Replacing this into equation (11) of full production costs and using definition (4) of full production costs without taxes yields

$$
C^{L}=(1-t) C^{L^{*}}+t\left(I^{L}-D^{L}-e^{L} G\right)
$$

If the landlord's imputed rental income is the rent he actually earns $\left(I^{L}=R\right)$ and that is equal to full production costs $C^{L}$, then $C^{L}$ appears on both sides of equation (21). Solving for $C^{L}$ yields

$$
C^{L}=C^{L^{*}}-t^{\prime}\left(D^{L}+e^{L} G\right)
$$

with

$$
t^{\prime}=\frac{t}{1-t}
$$

If the landlord were taxed on rent earned minus actual economic costs $\left(D^{L}=0\right)$ and if capital gains were fully taxed upon accrual $\left(e^{L}=0\right)$, the income tax would be perfectly neutral, without any incidence on rents. That 
is a well-known feature of taxes on pure economic profit. The supplementary deductibles $D^{L}$ and the tax-exempt part of accrued capital gains lower taxable rents, which lowers the tax on rents and so forth-hence the multiplier-type coefficient for $D^{L}$ in (22).

For the homeowner, an estimated implicit rental income $I^{O}$ is imputed for tax purposes for his use of his own dwelling, but he may deduct the interest paid and expenditures that maintain the value of the object. ${ }^{13} \mathrm{He}$ might also be granted supplementary deductibles $D^{O}$ similar to those of the landlord. If, however, not all of his expenses were deductible, say because there was a ceiling on interest deductions, then $D^{O}$ would capture those nondeductibles and be negative. The homeowner pays taxes

$$
T^{O}=t\left[I^{O}-K^{O}-D^{O}+\left(1-e^{O}\right) G\right]
$$

In order to test the tenure neutrality and equity of the stylised tax system, we need to compute the tax differential of equation (15) and compare it with the production cost differential for owner-occupied and rental housing services as in conditions (17) and (18). The following tax differential obtains, using equations (19), (20) and (24)

$$
\begin{aligned}
\Delta T= & t\left[\left(I^{O}-I^{L}\right)+\left(K^{L}-K^{O}\right)\right. \\
& \left.\left.+\left(D^{L}-D^{O}\right)-\left(e^{O}-e^{L}\right) G+D^{R}\right)\right]
\end{aligned}
$$

Thus, the difference in income tax burden imposed on owner-occupied and rental housing depends on the difference between the rental income imputed to the homeowner and the landlord, on the difference between the production costs of rental housing and those of owner-occupied housing (because they can be deducted), on the difference in supplementary deductibles, on the difference in capital gains exemption and on the deductible granted to the renter.

Next to tenure neutrality and equity, one is often interested in comparing housing income (and capital gains) taxation with the taxation of other goods and assets. That comparison must be performed for each tenure separately.
We shall consider that housing, rental or owner-occupied, is a tax shelter if its consumption allows paying less tax than the statutory tax applied to full pre-tax economic incomes. The tax shelter is computed as this amount minus effective tax, which is measured by the difference between available incomes without and with taxes. ${ }^{14}$ For the renter, that will include the possible tax advantages granted to the landlord, either because they are passed on to him or because he can benefit from them by investing his equity into rental housing. The difference in the tax shelters of the renter and the homeowner is equal to the tax differential $\Delta T$.

The renter's tax shelter is

$$
\begin{aligned}
S^{R} & =t\left(Y^{*}+i^{*} W\right)-\left(Y^{R^{*}}-Y^{R}\right) \\
& =R^{*}-R-T^{R}
\end{aligned}
$$

The second expression obtains from the definitions of $Y^{R^{*}}$ in equation (1) and of $Y^{R}$ in equation (8), but it could also serve as a definition of the tax shelter that the renter enjoys when consuming housing services. When the rents are equal to the full production costs of equations (4), (11) and (21) and the renter is granted the deductible of equation (19), his tax shelter becomes

$$
\begin{aligned}
S^{R}= & t i^{*} W-T^{L}-T^{R}=t\left(C^{L^{*}}-I^{L}+D^{L}\right. \\
& \left.+e^{L} G+D^{R}\right)
\end{aligned}
$$

If, in addition, the landlord's imputed rental income is the rent he actually earns $\left(I^{L}=R\right)$, the renter's tax shelter becomes, using equation (22)

$$
S^{R}=t^{\prime}\left(D^{L}+e^{L} G\right)+t D^{R}
$$

Rental housing is a tax shelter through the deductible $D^{R}$ granted to the renter and through the tax advantages granted to the landlord in the form of supplementary deductibles and partial exemption of capital gains.

The homeowner's tax shelter is defined in the same way as that of the renter

$$
\begin{aligned}
S^{O} & =t\left(Y^{*}+i^{*} W\right)-\left(Y^{O^{*}}-Y^{O}\right) \\
& =C^{O^{*}}-C^{O}
\end{aligned}
$$


where, $C^{O^{*}}$ and $C^{O}$ are the full production costs of owner-occupied housing without and with taxes of equations (5) and (12). Replacing those definitions into equation (29) and using equation (24) yields this tax shelter for the homeowner under the stylised tax system

$$
\begin{aligned}
S^{O} & =t i^{*} W-T^{O} \\
& =t\left(C^{O^{*}}-I^{O}+D^{O}+e^{O} G\right)
\end{aligned}
$$

The first equality in (30) is how Laidler (1969, table 1), computes tax subsidies to homeowners. Owner-occupied housing is a tax shelter through the difference between its full production costs and imputed rent and through the supplementary deductibles and partial exemption of capital gains.

\section{Solutions for Tenure-neutral and Equitable Housing Taxation}

For ease of interpretation and without loss of generality, we shall assume from now on that direct costs are higher for rental housing $\left(K^{L}>K^{O}\right.$, so $\Delta K>0$, an assumption for which arguments were given at the end of section 3. That implies that owner-occupied housing is the cheaper solution in the absence of all taxes. A tax system that is equitable and weakly neutral with respect to tenure choice reduces that cost advantage. A tax system that is strongly neutral leaves it unchanged. The tax system narrows the difference in available incomes if the tax differential of equation (25) is positive. That is the case when

$$
\begin{aligned}
I^{O}> & I^{L}-\left(K^{L}-K^{O}\right)+\left(D^{O}-D^{L}\right. \\
& \left.-D^{R}\right)+\left(e^{O}-e^{L}\right) G
\end{aligned}
$$

Tenure-equitable and tenure-neutral housing income taxation imposes a floor on the homeowner's imputed rent $I^{O}$, which is equal to the landlord's imputed rental income (which is generally the actual rent) minus the cost differential because the landlord can deduct greater costs $K^{L}$. That floor is raised if the homeowner is granted more generous additional deductibles and greater exemption of his capital gain.
More precise conditions for equity and neutrality can be found by aiming at a tax differential that lowers the difference in available income exactly in proportion $t$ of the income tax: $\Delta T=t \Delta K$. We shall call this 'strongly equitable'. Using equation (25), this is equivalent to

$$
\begin{gathered}
I^{O}-D^{O}-e^{O} G=I^{L}-D^{L}-e^{L} G \\
-D^{R}
\end{gathered}
$$

Several feasible tax solutions satisfy sufficient condition (32) for equity and weak tenure neutrality. By making the two tenures pay different amounts of taxes for the same housing consumption (unless production costs are equal: $K^{L}=K^{O}$ ), the solutions narrow the advantage of the cheaper tenure in proportion to the difference in production costs. If capital gains are not taxed in the same way for owner-occupied and rental housing $\left(e^{O} \neq e^{L}\right)$, that has to be picked up by the homeowner's imputed rent or additional deductibles (see equation (32)), which is clearly not practical. Hence, all the tax solutions presented here have $e^{O}=e^{L}$. Four practical tax solutions are proposed that lower the homeowner's available income advantage in proportion $t$. They are represented in Table 1 with their resulting tax shelters/tax burdens. Recall that the ratio $\Delta T / \Delta K$ is decisive for tax neutrality and equity. As indicated in equations (17) and (18), a tax solution is equitable when that ratio is between 0 and 1 . It is weakly tenure-neutral when it is less than 1 and strongly tenure-neutral when it is equal to 0 .

The four practical tax solutions that lower the homeowner's available income advantage in proportion $t$ are

(a) Equal imputed rental income, supplementary deductibles and capital gains taxation for homeowner and landlord; no deductible for renter $\left(I^{O}=I^{L}=I, \quad D^{O}=D^{L}=D\right.$, $\left.e^{O}=e^{L}=e, D^{R}=0\right)$.

It is plausible to grant the same supplementary deductibles to the homeowner as to the landlord as they are both taxed on the same imputed rental income, but the landlord will pay less tax because he has higher production 
Table 1. Tax solutions and their impacts on housing tax shelter, tenure neutrality and equity

\begin{tabular}{|c|c|c|c|c|}
\hline Tax solution & $\begin{array}{l}\text { Tax shelter } \\
\text { rental housing }\end{array}$ & $\begin{array}{c}\text { Tax shelter } \\
\text { owner-occupied } \\
\text { housing }\end{array}$ & Taxes paid & Equity and neutrality \\
\hline $\begin{array}{l}\text { a) Equal imputed rental income, } \\
\text { supplementary deductibles and } \\
\text { capital gains taxation for } \\
\text { homeowner and landlord; no } \\
\text { deductible for renter }\end{array}$ & $t\left(C^{L *}-I+D+e G\right)$ & $t\left(C^{O *}-I+D+e G\right)$ & $\Delta T=t \Delta K$ & $\begin{array}{c}\text { Strongly equitable } \\
\text { Weakly neutral }\end{array}$ \\
\hline $\begin{array}{l}\text { (b) Equal imputed rental income, } \\
\text { supplementary deductibles and } \\
\text { capital gains taxation for } \\
\text { homeowner and landlord; imputed } \\
\text { rental income is equal to market } \\
\text { rent; no deductible for renter }\end{array}$ & $t^{\prime}(D+e G)$ & $t^{\prime}(D+e G)-t \Delta K$ & $\Delta T=t \Delta K$ & $\begin{array}{c}\text { Strongly equitable } \\
\text { Weakly neutral }\end{array}$ \\
\hline $\begin{array}{l}\text { (c) Same imputed rental income for } \\
\text { homeowner and landlord, equal to } \\
\text { market rent; no supplementary } \\
\text { deductible for anyone and full } \\
\text { capital gains taxation upon accrual }\end{array}$ & 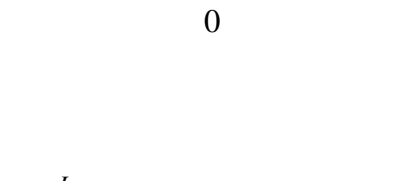 & $-t \Delta K$ & $\Delta T=t \Delta K$ & $\begin{array}{c}\text { Strongly equitable } \\
\text { Weakly neutral }\end{array}$ \\
\hline $\begin{array}{l}\text { (d) No imputed rent for homeowner } \\
\text { and renter may deduct his } \\
\text { landlord's imputed rent from his } \\
\text { own taxable income; equal } \\
\text { supplementary deductibles and } \\
\text { capital gains taxation for } \\
\text { homeowner and landlord }\end{array}$ & $t\left(C^{L *}+D+e G\right)$ & $t\left(C^{O *}+D+e G\right)$ & $\Delta T=t \Delta K$ & $\begin{array}{c}\text { Strongly equitable } \\
\text { Weakly neutral }\end{array}$ \\
\hline $\begin{array}{l}\text { (e) Owner-occupied housing treated } \\
\text { as a consumption good: no } \\
\text { imputed rental income, no } \\
\text { deduction and full capital gains } \\
\text { exemption for homeowner }\end{array}$ & $t\left(C^{L *}-I^{L}+D^{L}+e^{L} G+D^{R}\right)$ & $t i^{*} W$ & $T^{O}=0$ & $?$ \\
\hline
\end{tabular}


Table 1. Continued

\begin{tabular}{|c|c|c|c|c|}
\hline Tax solution & $\begin{array}{l}\text { Tax shelter } \\
\text { rental housing }\end{array}$ & $\begin{array}{c}\text { Tax shelter } \\
\text { owner-occupied } \\
\text { housing }\end{array}$ & Taxes paid & Equity and neutrality \\
\hline $\begin{array}{l}\text { (f) No imputed rental income, no } \\
\text { deduction and full capital gains } \\
\text { exemption for homeowner; the } \\
\text { renter may deduct his landlord's } \\
\text { taxable income from his own } \\
\text { taxable income }\end{array}$ & $t i^{*} W$ & $t i^{*} W$ & $T^{O}=T^{L}+T^{R}=0$ & $\begin{array}{l}\text { Very weakly equitable } \\
\text { Strongly neutral }\end{array}$ \\
\hline $\begin{array}{l}\text { (h) Equal imputed rental income, } \\
\text { supplementary deductibles and } \\
\text { capital gains taxation for } \\
\text { homeowner and landlord; the } \\
\text { direct cost differential between } \\
\text { rental and owner-occupied } \\
\text { housing is added to renter's } \\
\text { taxable income }\end{array}$ & $t\left(C^{O *}-I+D+e G\right)$ & $t\left(C^{O *}-I+D+e G\right)$ & $T^{O}=T^{L}+T^{R}$ & $\begin{array}{l}\text { Very weakly equitable } \\
\text { Strongly neutral }\end{array}$ \\
\hline
\end{tabular}


(i) Equal imputed rental income, sum $t\left(C^{O *}-I+D^{O}+e G\right)$ of ordinary and supplementary deductibles, and capital gains

taxation for homeowner and

landlord; no deductible for renter

(j) Same imputed rental income for

homeowner and landlord, equal to

market rent, and full capital gains

taxation upon accrual; no

supplementary deductible for

landlord; supplementary

deductible for homeowner equal

to the direct cost differential with rental housing

(k) Equal net imputed rental income

for homeowner and landlord,

equal to the reservation return on

equity; no deductible for anyone

nor any capital gains taxation

$$
t\left(C^{O *}-I+D^{O}+e G\right) \quad T^{O}=T^{L}+T^{R}
$$$$
T^{O}=T^{L}=t i^{*} W, T^{R}=0
$$

Very weakly equitable Strongly neutral
Very weakly equitable Strongly neutral

Notes: $C$ is full production costs of housing services, including the opportunity cost of funds and capital gains; $K$ is direct production costs with $\Delta K=K^{L}-K^{O} ; t$ is the (locally) proportional income tax rate; $I$ is imputed rental income; $D$ gathers supplementary deductibles; $e$ is the tax-exempt portion of accrued capital gains $G$; and $T$ is the sum of taxes levied in relation to housing with $\Delta T=T^{O}-T^{L}-T^{R}$. Asterisks denote pre-tax amounts and the superscripts $L, O$ and $R$ distinguish the variables for the landlord, the homeowner and the renter when necessary. A tax system is strongly equitable when it reduces the cost advantage of the cheaper tenure in proportion $t$ of the cost advantage and very weakly equitable when it imposes the same taxes on both tenures. It is weakly neutral when the taxes imposed on the cheaper tenure do not make it more expensive and strongly neutral when it imposes the same taxes on both tenures. 
costs to deduct. Under this solution, the tax shelters for rental and owner-occupied housing are respectively $S^{R}=t\left(C^{L *}-I+D+e G\right)$ and $S^{O}=t\left(C^{O *}-I+D+e G\right)$. Housing is a tax shelter to the extent that imputed incomes are less than pre-tax total production costs and that supplementary deductibles and partial capital gains exemption are granted.

(b) Equal imputed rental income, supplementary deductibles and capital gains taxation for homeowner and landlord; imputed rental income is equal to market rent; no deductible for renter $\left(I^{O}=I^{L}=R, \quad D^{O}=D^{L}=D\right.$, $\left.e^{O}=e^{L}=e, D^{R}=0\right)$.

This solution is a particular case of (a) for which the tax shelters reduce to $S^{R}=$ $t^{\prime}(D+e G)$ (equation (28)) and $S^{O}=$ $S^{R}-t\left(K^{L}-K^{O}\right)$ when the rent is equal to full production costs of rental housing. The renter benefits from the tax breaks granted to the landlord but the homeowner gets them too, directly and through a smaller imputed rent. However, the homeowner benefits from a smaller tax shelter than the renter because he is imputed a rental income based on the landlord's direct production costs $K^{L}$ but may deduct only his smaller costs $K^{O}$.

(c) Same imputed rental income for homeowner and landlord, equal to market rent; no supplementary deductible for anyone and full capital gains taxation upon accrual $\left(I^{O}=I^{L}=R, \quad D^{O}=D^{L}=0, \quad e^{O}=e^{L}=0\right.$, $\left.D^{R}=0\right)$.

This solution is a particular case of (b) that has no tax shelter anymore for the renter and a negative tax shelter $S^{O}=-t\left(K^{L}-K^{O}\right)$ for the homeowner due to the fact that he is imputed a rental income based on the landlord's production costs $K^{L}$ but may deduct only his smaller costs $K^{O}$. Since all and only economic costs are deductible, this solution has no impact on rents. It taxes the pure profit of the landlord, so that his return on equity is reduced just as if he had invested that equity in the reservation asset. However, this solution lowers the homeowner's available income in proportion to the difference between operating a rental and an owner-occupied dwelling. Thus, it reduces the available income differential between owner-occupied and rental housing by making the former less attractive.

(d) No imputed rent for homeowner and renter may deduct his landlord's imputed rent from his own taxable income; equal supplementary deductibles and capital gains taxation for homeowner and landlord $\left(I^{O}=0\right.$, $D^{O}=D^{L}=D, e^{O}=e^{L}=e, D^{R}=I^{L}$.

If the tax authority does not wish to impute to the homeowner the market rent as implicit income but allows him to deduct all operating and interest costs $K^{O}$, then equity and weak tenure neutrality can still be obtained by letting the renter deduct from his own taxable income the rental income that is imputed to his landlord. This is typically the rent he pays, in which case the solution obtains that Vickrey (1972) had proposed in despair over the political feasibility of full homeowner income taxation-to let the renter deduct his rent from his taxable income. This solution creates tax shelters $S^{R}=t\left(C^{L *}+D+e G\right)$ and $S^{O}=t\left(C^{O *}+\right.$ $D+e G)$ of which the main components are the exempted explicit or implicit rentals valued at full production costs. ${ }^{15}$ The renter's tax shelter is a little more generous because he may deduct a rent including higher production costs than the tax-exempt implicit rent of the homeowner. Those tax shelters do not disappear even when the homeowner and the landlord are not granted any supplementary deductibles and capital gains are fully taxed upon accrual.

It is not necessary that the tax system reduce the difference in available incomes in the proportion of the statutory tax rate $t$ to be equitable or weakly tenure-neutral. Many more conditions can be found for the stylised tax system, but they may be much more difficult to implement if they need complicated calculation of the imputed rent and personalised conditions.

One solution frequently advocated and applied in some countries such as Australia is to treat owner-occupied housing as a regular consumption good. In our model formulation, this corresponds to $T^{O}=0$ in equation (24), which can be thus obtained. 
(e) No imputed rental income, no deduction and full capital gains exemption for homeowner $\left(I^{O}=0, D^{O}=-K^{O}, e^{O}=1\right)$.

Since the homeowner pays no housingrelated income taxes, this solution is weakly neutral when rental housing is positively taxed, simply because it makes owner-occupied housing even more advantageous. That would not be equitable, however. For tenure equity, rental housing must be subsidised overall $\left(T^{L}+T^{R}<0\right)$, but not so that the subsidies more than compensate the cost advantage of owner-occupied housing $\left(-T^{L}-T^{R}<\Delta K\right)$. The renter enjoys the generic tax shelter of equation (27) and the homeowner gets $S^{O}=t i^{*} W$ or the amount of the statutory tax on the implicit return on his equity. Indeed, not including housing at all in the taxation of the homeowner's income amounts to exempting the implicit return on his equity or, equivalently, to allow investment in a tax-free good but only for homeowners (Bourassa and Hendershott, 1994).

As $\Delta K$ might be small, there is a risk that subsidies to rental housing more than compensate the cost advantage of owner-occupied housing. So if rental housing is also to be tax-favoured, the safest way is to let it also enjoy income tax exemption, by exempting the landlord from income taxation just like the homeowner and to not grant the renter any deductible related to his housing consumption $\left(T^{L}=T^{R}=0\right)$. In fact, rental housing tax exemption $\left(T^{L}+T^{R}=0\right)$ can even be obtained when the landlord is taxed regularly on earned rent minus costs, provided the renter is allowed to deduct from his own taxable income his landlord's taxable income.

(f) No imputed rental income, no deduction and full capital gains exemption for homeowner; the renter may deduct his landlord's taxable income from his own taxable income $\left(I^{O}=0, \quad D^{O}=-K^{O}, \quad e^{O}=1, \quad D^{R}=\right.$ $\left.I^{L}-K^{L}-D^{L}+\left(1-e^{L}\right) G\right)$.

The renter should not be allowed to deduct his full rent from his taxable income but only the portion of his rent on which the landlord is taxed. With this tax solution, the tax shelters for rental and owner-occupied housing are equal: $S^{R}=S^{O}=t i^{*} W$. Of course, this solution is more practical when the landlord is also fully exempted from capital gains taxation and there would still remain an apportionment problem of the landlord's taxable income when he owns more than one rental dwelling.

Once it is recognised that treating owneroccupied housing like a pure consumption good allows homeowners to shelter equity, compensation can be sought in letting the renter shelter the same amount of equity, as proposed by Hendershott and $\mathrm{Hu}$ (1980). In the terms of the present model.

(g) No imputed rental income, no deduction and full capital gains exemption for homeowner; no supplementary deductible and full capital gains taxation upon accrual for landlord; the renter's return on his equity is tax exempt $\left(I^{O}=0, D^{O}=-K^{O}, e^{O}=1\right.$, $\left.I^{L}=R, D^{L}=e^{L}=0, D^{R}=i^{*} W\right)$.

The landlord is taxed on his pure profit ( $\left.T^{L}=t i^{*} W\right)$ and the rent is equal to production costs without taxes $\left(R=C^{L^{*}}\right)$. The tax shelter for rental housing is directly earned by the renter, nothing being passed to him through his rent. It corresponds to the tax the renter would normally have to pay on his financial return $\left(S^{R}=t i^{*} W\right)$ and is equal to the homeowner's tax shelter provided the renter's equity is the same as the equity invested by the homeowner in his property. Again, $T^{O}=T^{L}+T^{R}=0$.

Those solutions that exempt both rental and owner-occupied housing from income taxation are obviously strongly neutral and weakly equitable. They are not neutral with respect to portfolio allocation and housing financing (nor is solution (e)), since offering a tax shelter to equity tilts the playing-field against debt. ${ }^{16}$

In general, the tax system is strongly tenure-neutral if $T^{O}=T^{L}+T^{R}$, even when those taxes are different from 0. For the stylised tax system (equation (25)), that condition is equivalent to

$$
\begin{aligned}
& I^{O}-K^{O}-D^{O}-e^{O} G \\
& \quad=I^{L}-K^{L}-D^{L}-e^{L} G-D^{R}
\end{aligned}
$$


Equation (33) shows that strong tenure neutrality is not obtained by simply imputing for the homeowner an income equal to the market rent $\left(I^{O}=R\right)$, even when the landlord's imputed rental income is the rent he earns $\left(I^{L}=R\right)$. It is necessary to take into consideration the difference in production costs if the tax system is to preserve that difference. Strong tenure neutrality could be obtained by offering the renter a compensating deductible equal to the differential in costs and taxes between the homeowner and the landlord. This become practically feasible when those differentials are reduced to the minimum-i.e. when the homeowner is taxed as much as possible like the landlord. Here are two proposals.

(h) Equal imputed rental income, supplementary deductibles and capital gains taxation for homeowner and landlord; the direct cost differential between rental and owner-occupied housing is added to renter's taxable income $\left(I^{O}=I^{L}=I, \quad D^{O}=D^{L}=D, \quad e^{O}=e^{L}=e\right.$, $\left.D^{R}=K^{O}-K^{L}\right)$

The extra direct costs of rental housing must be added to the renter's taxable income $\left(D^{R}<0\right)$ because the landlord may deduct more costs from his taxable income than the homeowner. The reason for this becomes clear when the imputed rental income for both landlord and homeowner is equal to the market rent, because that overassesses the homeowner's income relative to his own lower direct production costs. Rental housing enjoys the same generic tax shelter of equation (30) as owner-occupied housing. This tax solution is weakly equitable and strongly neutral. It resembles solution (a), which was strongly equitable and weakly neutral by not imputing any additional taxable income to the renter. Obviously, solution (h) is not likely to be very popular with renters.

(i) Equal imputed rental income, sum of ordinary and supplementary deductibles, and capital gains taxation for homeowner and landlord; no deductible for renter $\left(I^{O}=I^{L}=I, \quad D^{O}+K^{O}=D^{L}+K^{L}, \quad e^{O}=\right.$ $\left.e^{L}=e, D^{R}=0\right)$.

In this case, the overassessment of the homeowner's housing income is offset by greater supplementary deductibles by the amount of the difference between the direct production costs of rental and owner-occupied housing. Rental housing enjoys the same generic tax shelter of equation (30) as owner-occupied housing. The difference with solution (h) is that the supplementary deductibles granted to the landlord and the homeowner are not the same.

Further solutions for strongly tenure-neutral taxation can be obtained by seeking a common value for the tax burden imposed on owneroccupied and rental housing, particularly when that common value is equal to the statutory tax on the implicit return on equity $\mathrm{ti}^{*} \mathrm{~W}$. In that case, both tax shelters are reduced to zero and full neutrality obtains as defined by Haffner (2000) — that is, also with respect to non-housing investment. Again, many solutions are possible to obtain $S^{R}=t\left(i^{*} W+\right.$ $\left.K^{L}-I^{L}+D^{L}+e^{L} G+D^{R}\right)=0$ and a similar expression for the homeowner. Two relatively practical ones are proposed here

(j) Same imputed rental income for homeowner and landlord, equal to market rent, and full capital gains taxation upon accrual; no supplementary deductible for landlord; supplementary deductible for homeowner equal to the direct cost differential with rental housing $\quad\left(I^{O}=I^{L}=R, \quad D^{O}=K^{L}-K^{O}\right.$, $\left.D^{L}=0, e^{O}=e^{L}=0, D^{R}=0\right)$.

This solution is very similar to solution (c) but eliminates the homeowner's negative tax shelter by allowing him supplementary deductibles that offset the fact that he is imputed a rental income based on the landlord's production costs $K^{L}$ but may deduct only his smaller costs $K^{O}$. Alternatively, one could grant no supplementary deductible to the homeowner $\left(D^{O}=0\right)$ and impute rental income equal to the full pre-tax production costs of owner-occupied housing $\left(I^{O}=C^{O^{*}}\right)$.

(k) Equal net imputed rental income for homeowner and landlord, equal to the reservation return on equity; no deductible for anyone nor any capital gains taxation $\left(I^{O}=I^{L}=i^{*} W, \quad D^{O}=-K^{O}, \quad D^{L}=-K^{L}\right.$, $\left.e^{O}=e^{L}=1, D^{R}=0\right)$.

This solution was proposed by Vickrey (1947). It avoids the need for full capital 
gains taxation upon accrual and still eliminates tax shelters. Both landlord and homeowner pay taxes $t i^{*} W$ for their housing investment. The same results can be obtained by counting a return not on equity but on the property's value as housing income for the landlord and the homeowner and letting them deduct mortgage interest and nothing else related to housing. That is the 'property tax' proposal of Englund (2003). A third variant estimates the landlord's and homeowner's housing income at full production costs, including the opportunity cost of equity $\quad\left(I^{L}=K^{L}+i^{*} W, \quad I^{O}=K^{O}+i^{*} W\right)$, and allows them to deduct housing-related expenses including mortgage interest. Obviously, this is a less practical solution.

In 2000, Denmark replaced the imputed rent it had added to other capital income since 1903 by a 'property value tax' of 1 per cent of the publicly assessed property value. This can be seen as a 16.7 per cent flat tax on 6 per cent return or a 12.5 per cent flat tax on 8 per cent return if the property is fully equity owned (Lunde, 2004). This Danish solution resembles Englund's 'property tax' proposal. It is not equivalent, though, if that implicit property income is not adjusted every year to reflect current market returns for assets of equivalent risk and liquidity.

Defining the homeowner's taxable income from his housing as equal to the implicit return on the locked-in equity or as a general return on the asset value, instead of computing an implicit rent and allowing him to deduct costs, is an attractive solution for countries that, unlike Switzerland, have only small or heavily regulated rental markets, as suggested by Hughes (1980). It should not be harder to implement than an imputed rental income, particularly when properties are regularly assessed anyway.

\section{Conclusions}

In the case of housing, testing the equity and the tenure neutrality of the tax system cannot be limited to comparing the taxes paid by the renter and the homeowner. It is necessary also to include the taxes paid by the landlord, as the renter is the only 'consumer' to bear those taxes, through higher rent. ${ }^{17}$ It is equally necessary to take into consideration the costs borne by the homeowner in comparison with those of the renter and especially the landlord. The homeowner can typically 'produce' housing services at a lower cost than can the landlord: smaller management costs, maintenance costs, no loss of rental income. Those cost advantages compound the tax advantages when the implicit rental income is imputed very conservatively to render ownership quite attractive, provided that the landlord and the homeowner purchase the same dwelling at the same price and obtain the same credit terms. A premium for retail sales of dwellings - typically for condominiums-and difficulties with financing the purchase can easily wipe out the other economic advantages of homeownership. Shorter holding periods that force homeowners to incur high transaction costs more frequently are also an argument against ownership.

Tenure neutrality and equity do not always accord. For the tax system to be neutral with respect to tenure choice, that tenure which is more advantageous should remain so after taxes. For strong tenure neutrality, the financial advantage should even be preserved exactly. Equity, for its part, requires that those who benefit from cheaper tenure pay more tax, even if part of the advantage is thereby taken away. If households choose the tenure that implies higher available income, whatever the size of the gain, then an equitable tax system is also neutral. Obviously, financial advantage is but one aspect of tenure choice. A reduced available income advantage lowers the weight of that element of choice and the scale may tip for some households. In that case, the equitable tax system is not tenure-neutral.

Four feasible tax solutions were shown that reduce the homeowner's cost advantage in the proportion of the income tax, which we therefore called strongly equitable. Three of them impute the same rental income to the homeowner as to the landlord and grant them the same supplementary deductibles and partial capital gains exemption. That reduces the cost advantage of the homeowner because he 
may deduct only his smaller direct production costs for an imputed rent based on the landlord's higher costs. The fourth strongly equitable solution has no imputed rental income for the homeowner but the renter is allowed to deduct his rent from his taxable income. All those solutions yield tax shelters for owner-occupied and rental housing related to the supplementary deductibles and partial capital gains exemption. With the fourth solution, the tax shelter is markedly increased by the exemption of rental income.

We also showed that leaving owneroccupied housing fully out of income taxation (no imputed rental income or capital gains taxation and no deductibles) allows the homeowner a tax shelter equal to the amount of the statutory tax on the implicit return on his equity. That solution is not equitable but it is weakly neutral in making the cheaper tenure even more attractive (unless favourable tax treatment of rental housing offsets its cost disadvantage). Of course, rental housing could also be exempted from income taxation, in which case income taxation would be strongly tenure-neutral. That would grant rental housing the same tax-sheltered return on equity as owner-occupied housing. Such a solution could even be obtained with regular income taxation of the landlord, provided the renter were allowed to deduct his landlord's taxable income related to his dwelling (rent minus deductible costs, not the full rent) from his own taxable income. If the landlord were taxed on pure profit (no supplementary deductibles and full capital gains taxation upon accrual), that solution could also be obtained by exempting the renter's financial return on his wealth, provided that it were the same as the equity sheltered in his property by the homeowner.

Many solutions can be imagined that impose the same taxes on owner-occupied and rental housing and thus achieve strong tenure neutrality, but only very weak equity. We proposed four, two of which simply equate the taxes on owner-occupied and rental housing at any value and two that set those taxes at the level of the statutory tax on the implicit return on equity and thus eliminate all tax shelters for owner-occupied and rental housing. The first two tax solutions impute the same rental income for the homeowner and the landlord (not necessarily the market rent) and grant them the same partial exemption of capital gains. One of those solutions has the same supplementary deductibles for homeowner and landlord, which implies a tax disadvantage for the homeowner, which must be offset by adding the direct cost differential between rental and owner-occupied housing to the renter's income. The other tax solution has no imputation for the renter but an extra deductible for the homeowner equal to that cost differential. The two tax solutions that eliminate all tax shelters do so in very different ways. The first one imputes the market rent as income to the homeowner and landlord, taxes capital gains fully upon accrual, allows the landlord to deduct only actual costs but grants the homeowner a supplementary deductible equal to the cost differential. That is designed to offset the overestimation of his implicit rental income that is based on the production cost of rental housing. The second solution has no capital gains taxation and no deductibles at all but imputes to the homeowner and landlord housing income equal to the implicit return on equity.

Clearly, tax shelters are only eliminated in very weakly equitable tax solutions, which impose the same taxes on owner-occupied and rental housing even when one tenure enjoys a production cost advantage. There is, therefore, a trade-off between equity and the undesirable secondary effects of tax shelters, such as inefficient investment in housing and distortions in maintenance and financing. Finally, the practical feasibility, in particular as regards the assessment of accrued capital gains and implicit rental income, and the consequences for public budgets ought to be considered when comparing tax solutions.

\section{Notes}

1. A mitigating argument could be that the renter earns income in cash on his equity whereas "investment in an owner-occupied house has the peculiarity that the whole 
return must be currently consumed" (Goode, 1960, p. 512). That difference matters when the implicit rent exceeds what a household would spend for its housing in a frictionless world, which concerns particulary the elderly.

2. This is not so much a condition of equity as a condition of feasibility: no one would make the efforts required to earn higher income to end up with lower income after taxes.

3. In addition, Bruce and Holtz-Eakin (1999) have shown that even fundamental reforms of housing taxation have little impact on house prices once the adjustments in consumption and investment are taken into account.

4. Location has no great effect for its part. Indeed, the evolution of prices is rather uniform over the different parts of the Randstad.

5. Spending for maintenance is assumed sufficient to prevent physical depreciation.

6. These assumptions are similar to those of Giertz and Sullivan (1978) who compare a homeowner with an identical tenant who invests his equity in rental housing rented to a third party.

7. Megbolugbe and Linneman (1993) use the more general term 'managerial efficiency'.

8. Harding et al. (2000) actually develop a different explanation for that result. They believe that highly indebted homeowners consider the option to default, in which case maintenance spending is of no advantage to them. They even develop a further idea in response to Shilling et al. (1991) that homeowners do not bear the full consequences of poor care and maintenance, just like the renters, because future buyers also fail to measure all damages. This is not confirmed by their data.

9. Capone (1995) sets these costs at 2 per cent of house value before tax for his simulations.

10. Such allowances exist in 4 Swiss cantons out of 26 , with the purpose of setting tenants on a more equal footing with homeowners. In one canton, all taxpayers are allowed to deduct from their taxable income that part of their annual rent (or imputed rent) that exceeds 20 per cent of their net income, with a ceiling. Since imputed rents are set rather conservatively, it is essentially tenants who benefit from that allowance. In two cantons, tenants may deduct 20 per cent of their rent with a ceiling. In one canton, tenants are allowed a fixed amount.

11. The other countries do not allow unlimited deductibility of mortgage interest paid.

12. Flat rates have been found repeatedly to be good approximations of effective tax schedules when deductions are taken into account (for Switzerland, see Mottu, 1997). Here, it is sufficient that the marginal tax rate be the same for the landlord, renter and homeowner, who are supposed to enjoy the same non-housing incomes and wealth.

13. The UK used estimated rents for tax purposes from the beginning of income tax in 1803 until 1963. Schedule A, the tax levied on income from land and buildings, taxed the imputed income of homeowners. In the years before abolition, the tax progressively lost its 'bite' as rent estimations lagged inflation while deductions were allowed on current terms. Abolition implied small revenue losses (Cullingworth, 1979).

14. This tax shelter definition exactly corresponds to the difference in user costs before and after taxes.

15. In the US, tenants were allowed to deduct annual rental payments on their residences under the Civil War income tax (Goode, 1960). Goode wrote: "The Civil War tax appears to have resulted in much more nearly equal treatment of renters and owner-occupants than has been achieved in moder income tax law" (p. 523). However, he continues, "allowance of a deduction for rent ... cannot be recommended in view of its revenue cost and the favouritism it would show to housing compared with other forms of consumption".

16. It might appear from Table 1 that the tax shelters depend on the amount of equity $W$ under solution (d) too, since the full costs $C$ include $i^{*} W$, but they also include direct costs $K$, which include the cost of debt $i^{*}(P-W)$, where $P$ would be the value of the property. Thus, the term in $W$ washes out unless interest rates on debt and equity are different.

17. The rent could actually be lower than production costs, if rental housing is a tax shelter.

\section{References}

AARON, H. (1970) Income taxes and housing, American Economic Review, 60(5), pp. 789806.

Blackley, D. M. and Follain, J. R. (1996) In search of empirical evidence that links rent and user cost, Regional Science and Urban Economics, 26(3/4), pp. 409-431.

Bourassa, S. C. and Hendershott, P. H. (1994) On the equity effects of taxing imputed rent: evidence from Australia, Housing Policy Debate, 5(1), pp. 73-95. 
BRUCE, D. and HoltZ-EaKIN, D. (1999) Fundamental tax reform and residential housing, Journal of Housing Economics, 8(4), pp. 249-271.

CAPONE, C. A. J. (1995) Taxation and housing tenure choice: the case for moderate-income homeownership, Journal of Housing Economics, 4(4), pp. 328-349.

Cullingworth, J. B. (1979) Essays on Housing Policy: The British Scene. London: George Allen and Unwin.

DiPasquale, D. and Wheaton, W. C. (1992) The cost of capital, tax reform, and the future of the rental housing market, Journal of Urban Economics, 31(3), pp. 337-359.

ElsingA, M. (1996) Relative cost of owner-occupation and renting: a study of six Dutch neighborhoods, HBE Netherlands Journal of Housing and the Built Environment, 11(2), pp. 131-150.

ENGLund, P. (2003) Taxing residential housing capital, Urban Studies, 40(5/6), pp. 937-952.

Feldstein, M. (1976) On the theory of tax reform, Journal of Public Economics, 6(1/2), pp. 77-104.

Giertz, J. F. and Sullivan, D. H. (1978) Housing tenure and horizontal equity, National Tax Journal, 31(4), pp. 329-338.

GoodE, R. (1960) Imputed rent of owner-occupied dwellings under the income tax, Journal of Finance, 15(4), pp. 504-530.

Haffner, M. E. A. (2000) Costs and fiscal subsidies in owner occupation: method and outcomes, Journal of Housing and the Built Environment, 15(1), pp. 53-69.

HAfFNeR, M. E. A. (2003) Tenure neutrality, a financial-economic interpretation, Housing, Theory and Society, 20(2), pp. 72-85.

Harding, J., Miceli, T. J. and Sirmans, C. F. (2000) Do owners take better care of their housing than renters?, Real Estate Economics, 28(4), pp. 663-681.

HendershotT, P. H. and Hu, S.-C. (1980) Government-induced biases in the allocation of the stock of fixed capital in the United States, in: G. M. von Furstenberg (Ed.) Capital, Efficiency, and Growth, pp. 323-360. Cambridge, MA: Ballinger.

Hendershott, P. H. and Shilling, J. D. (1982) The economics of tenure choice, 1955-1979, in: C. F. Sirmans (Ed.) Research in Real Estate, Vol. 1, pp. 105-133. Greenwich, CT: JAI Press.

Henderson, J. V. and IoANnides, Y. M. (1983) A model of housing tenure choice, American Economic Review, 73(1), pp. 98-113.

Hughes, G. A. (1980) Housing and the tax system, in: G. A. Hughes and G. M. Heals (Eds) Public Policy and the Tax System, pp. 67-105. London: George Allen and Unwin.

LAIDLER, D. (1969) Income tax incentives for owner-occupied housing, in: A. C. HARBERGER and M. J. BAILEY (Eds) The Taxation of Income from Capital, pp. 50-76. Washington. DC: Brookings Institution.

LinNemAn, P. (1985) An economic analysis of the homeownership decision, Journal of Urban Economics, 17(2), pp. 230-246.

LUNDE, J. (2004) Lack of balance in after-tax returns-lack of tenure neutrality: the Danish case. Working Paper No. 2004-3, Department of Finance, Copenhagen Business School.

Lundqvist, L. J. (1986) Housing Policy and Equality: A Comparative Study of Tenure Conversions and Their Effects. London: Croom Helm.

Megbolugbe, I. F. and Linneman, P. D. (1993) Home ownership, Urban Studies, 30(4/5), pp. 659-682.

MotTu, E. (1997) Progressivité de l'impôt fédéral direct et de la tva en Suisse, Swiss Journal of Economics and Statistics, 133(4), pp. 709-740.

OECD (ORgANiSATION FOR ECONOMIC CO-OPERATION AND Development) (1994) Taxation and Household Saving. Paris: OECD.

Poterba, J. M. (1990) Taxation and housing markets: preliminary evidence on the effects of recent tax reforms, in: J. SLemrod (Ed.) Do Taxes Matter?, pp. 141-160. Cambridge, MA: MIT Press.

Rosen, H. S. (1984) Housing subsidies: effects on housing decisions, efficiency, and equity, in: A. J. Auerbach and M. Feldstein (Eds) Handbook of Public Economics, Vol. 1, pp. 375420. Amsterdam: North Holland.

Rosen, H. S. and Rosen, K. T. (1980) Federal taxes and homeownership: evidence from time series, Journal of Political Economy, 88(1), pp. 59-75.

Shelton, J. P. (1968) The cost of renting versus owning a home, Land Economics, 44, pp. $59-72$.

Shilling, J., Sirmans, C. F. and Dombrow, J. (1991) Measuring depreciation in single-family rental and owner-occupied housing, Journal of Housing Economics, 1(2), pp. 368-383.

Titman, S. (1982) The effects of anticipated inflation on housing market equilibrium, Journal of Finance, 37(3), pp. 827-842.

Vickrey, W. S. (1947) Agenda for Progressive Taxation, 1st edn. New York: Ronald Press [reprinted 1972, Clifton, NJ: A. M. Kelley].

ViCKREY, W. S. (1972) An updated agenda for progressive taxation, American Economic Review Papers and Proceedings, 82(2), pp. 257-262.

White, M. H. and White, L. J. (1977) The tax subsidy to owner-occupied housing: who benefits?, Journal of Public Economics, 7(1), pp. 111-126. 